\title{
Crossing Canadian Cultural Borders: A study of the Aboriginal/White Stereotypical Relations in George Ryga's The Ecstasy of Rita Joe
}

\author{
Maram M. Samman* \\ Taibah University, Saudi Arabia
}

Corresponding Author: Maram M. Samman, E-mail: smarams2001@hotmail.com

\section{ARTICLE INFO}

Article history

Received: August 14, 2017

Accepted: October 20, 2017

Published: January 05, 2018

Volume: 7 Issue: 1

Advance access: December 2017

Conflicts of interest: None Funding: None

\begin{abstract}
This paper traces the intercultural journey of a young Aboriginal girl into the hegemonic white society. Rita Joe crossed the imaginary border that separates her reserve from the other Canadian society living in the urban developed city. Through this play, George Ryga aims at achieving liberation and social equality for the Aboriginals who are considered a colonized minority in their land. The research illustrates how Ryga represented his personal version of the colonial Aboriginal history to provide an empowering body narrative that supports their identity in the present and resists the erosion of their culture and tradition. The play makes very strong statements to preserve the family, history and local heritage against this forced assimilation. It tells the truth as its playwright saw it. The play is about the trail of Rita Joe after she moved from her reserve in pursuit of the illusion of the city where she thought she would find freedom and social equality. In fact the audience and the readers are all on trial. Ryga is pointing fingers at everyone who is responsible for the plights of the Aboriginals as it is clear in the play. He questions the Whites' stereotypical stand against the Aboriginals. The play is a direct criticism of the political, social and cultural systems in Canada. The paper reveals Aboriginals' acts of opposition to racism, assimilation and colonization as represented in The Ecstasy of Rita Joe.
\end{abstract}

Key words: Aboriginals, Assimilation, Canadian, Crossing, Cultural borders, George Ryga

Crossing Canadian Cultural Borders: A study of the Aboriginal/White Stereotypical Relations in George Ryga's The Ecstasy of Rita Joe.

As a direct result of the settler colonization in Canada, many Aboriginals were simply forced to give up their identity, their language and their past life, and adapt to the Whites' ways of living. The colonial Relocation Program has helped to draw an imaginary line between the Aboriginals in their reserves and the Whites in their newly built, urban, and developed cities. In general, these border lines can be ethnic, racial as well as based on social class and/ or religion. In George Ryga's The Ecstasy of Rita Joe, the title character is a young Aboriginal girl who is treated as an outsider in her own country; she is stigmatized because of her identity as an Aboriginal. During the play, she is judged and convicted more than eight times. Her offense is simply crossing from her reserve in pursuit of the illusion of the city where she thought she would find freedom and social equality. Shockingly, she ends up dead on the roads of the city with a "twisted, broken body" (124). She is the victim of the Whites' prejudices against the Aboriginals.

Historically, Canada has been inhabited by the Aboriginals long before the European settlers reached its shores. Natives and Aboriginals are terms used in this paper interchangeably, to embrace "a wide range of peoples in Cana- da, which include Indians, Metis, Inuit, and Native peoples" (Kirkness and Bowman 4). The Western colonizers have tried hard to subjugate the Aboriginals from the early days of colonization. This paper aspires to draw the public attention to some of the culturally, socially, and politically inhumane results of these settlements, as represented in George Ryga's The Ecstasy of Rita Joe. The Western newcomers have launched a crusade-like campaign to assimilate the Indians and cure them from their problem i.e. Aboriginality. However, their colonial plans have always had a bigger fish to fry. In Children of the Dragonfly: Native American Voices on Child Custody and Education, Robert Benson states that "the goal of the Europeans has always been to gain absolute possession... To achieve that goal; they have worked, and still are trying by all possible means, to exterminate the native populations... [simply because of] their inheritance - this part of the earth is wanted" (x). New tides of Anglo immigrants moved to these new lands to exploit its native inhabitants and form new communities. Consequently, the Natives were dispossessed of the lands, on which they had lived for centuries, in favour of the imperial expansion of the Whites to build highly developed cities for them. As a part of the Relocation Program, the Aboriginals were forced to "movement controls" and "surrender title to their land, [and] they were granted lands to live on which are known as reserves [but] 
are held directly under the Crown" (Douglas 9-71). Some of these new comers believed that these remnants of the dying, savage culture are better off being restrained in these reserves to die either literally or metaphorically through being transformed by education and evangelization. In "Aboriginal Public Policy in Urban Areas", Evelyn Peters states that almost all these "resource-poor reserves" were "located at a distance from urban centers" (13).

In the play, Rita Joe has crossed the border that separates her reserve from the Canadian society living in the urban, developed city. This intercultural journey of the Aboriginal, Canadian, young girl into the hegemonic White society is reviewed by Ben Metcalfe, from the Vancouver $\mathrm{CBC}$, as "a human experience. an act of communion in which our own participation is inescapable" (qtd. in Ryga, Ecstasy 127). By the early 1970s, The Oxford Anthology of Canadian Literature describes George Ryga (1932-1987) as "the most successful theatre dramatist in English Canada" (qtd. in Hoffman, The Ecstasy 10). Ryga was born to poor, Ukrainian, immigrant parents. During his life, he faced a dual dilemma - as a colonizer from the West as well as the colonized who is regarded as a second-class citizen. Yet, it is interesting to notice that his works "exemplify more than anything else the difficulty of cultural production within the invader-settler colony" (Hoffman, The Ecstasy 13). Instead of adapting to the Anglo-Canadian mainstream, he starts representing the plight of the Natives living in Canada. Most of his plays "address themes of human struggle; many tackle issues of Canadian identity" (Hoffman, George Ryga 9). Through his works, Ryga has managed to secure a prestigious place in Canadian literature, especially in drama. Undeniably, "he is an enduring presence in the larger, ongoing construction of post-colonial Canadian culture" (Hoffman, George Ryga 10). His identity as an immigrant has infl enced almost all his literary works, which are mostly related to the minorities and resistance. Lisa Grekul praises his genius, saying that "we see in Ryga's works a writer whose commitment to reclaiming and proclaiming [his] identity as Ukrainian-Canadian comes through not only the stories he uses but also in the language and genres that he uses to tell them" (61). George Ryga is commonly known to be "Outspoken, abrasive, and always fiercely committed to social justice and the defense of human dignity and struggle", one who has created an "impressive body of dramatic work that is less known than it should be in Canada" (Wasserman 23). Many critics believe that The Ecstasy of Rita Joe is a "familiar Canadian classic" (Hoffman, George Ryga 9) and one of the landmarks in Native Theatre (Hoffman, The Ecstasy 11). Talking about Native theatre in the introduction to his anthology, Jerry Wasserman states that "within the arrival of The Ecstasy of Rita Joe (1967), Canadian plays ceased to be a rarity in English-speaking Canada" because it "had touched the nerve of English Canada" (14-15). This paper attempts to show how provocative his play is in its representation of some of the difficulties faced by a young Aboriginal girl as she searches for social equality. Unfortunately, the play has not yet received serious investigation, despite being its writer's masterpiece. Expectantly, this study shall contribute to acclaiming Ryga and his play with the credit they deserve. Herein, it is anticipated that the interest of the study will stimulate more critical and academic readings of George Ryga's literary works.

To deliver his humane message, Ryga chooses a peculiar setting for his play. The backstage consists of "a mountain of cyclorama. In front of the cyclorama, there is a darker maze curtain to suggest gloom and confusion, and a cityscape." The setting of the play "creates a sense of compression of stage into the auditorium." Then, a clerk shouts: "This court is in session. All present will rise...." (16). All these propose that not only Rita, but the audience is also on trial. Ryga is pointing fingers at everyone who is responsible for the plight of the Aboriginals. Another important aspect of the stage setting is the curtains. The stage direction clearly points out, "No curtain is used during the play. At the opening, intermission and conclusion of the play, the curtain remains up." This idea emphasises that the beginning of the story is not here. The real story about the Aboriginals' suffering begins long ago, has many details, and is even more complicated than the immense suffering that is depicted in the play. What we are witnessing is only a piece from the bigger picture. Instead of using the traditional curtains, "the onus for isolating scenes from the past and present in RITA JOE's life falls on highlight lighting" (15). All throughout the play, we encounter frequent instances where "faint light on the $M A G$ ISTRATE brightens" (20) and "the light isolation between her and JAIMIE deepens, as the scene turns into courtroom again" (22).

In the trial, Rita is the accused Aboriginal female who stands alone without any legal representation, in an attempt to defend herself in front of an unsympathetic White Magistrate. The incidents of the story are linked by Rita's memory and associations. She appears in front of the Magistrate more than eight times. In the beginning, he informs Rita that "the charge against you this morning is vagrancy" (22). However, he later continues, "the charge against you this morning is prostitution" (39). The Policeman admits that "Rita Joe established herself as something of a disruptive influence... A trouble maker!" (49). It does not matter how hard she tries to live up to the Whites' standards; she is stigmatized because of her identity as an Aboriginal. The Magistrate informs her that he knows, by experience, that she "will be back...always be back...growing older, filthier...looking more like stone and prison bars" (117). That is what really happened, Rita gets trapped. She states that she "can't leave town. Everytime I try, they put me in jail" (22). At the end of this dream-like play, she is dead, as a result of the cruelty of the society. Her death is symbolic of what Ryga believes to be the catastrophic end of the Canadian society. In Summerland, he expresses what he feels is the solution to the Aboriginals' dilemma. He acknowledges that the White settlers are facing "the choice of either destroying Our Indian people or giving them an opportunity for life, we could do neither" (4). He believes the answer is to let the Aboriginals live in peace. In fact, Rita struggles in vain to find a place for herself in the city, where she faces her inexorable rape-murder. Unfortunately, Rita drowns in the White tide that surrounds 
her in the city. The cold Magistrate directs his speech at Rita, as a representative of all Aboriginals, saying:

The cities are open to you to come and go as you wish, yet you gravitate to the slums and skid rows and the shanty-town fringes. You become a whore, drunkard, user of narcotics... at best, dying of illness or malnutrition... At worse, kicked or beaten to death by some angry white scum who finds in you something lower than himself to pound his frustrations out on! What's to be done? You Indians seem to be incapable of taking action to help yourselves. Someone must care for you... Who? For how long? (118)

It is true that the cities are open for the Natives, but the Whites have never embraced them. The Magistrate's saying echoes Michael Kearney's comments on the supposed holy mission of the Western settlers to "humanize--while differentiating" the Aboriginals (264). The Whites need to possess the necessary amount of cultural consciousness required for an engagement with the other, "on all levels and thus they are no longer exotic or different but another human being with similar wants and needs as oneself. The real description to this process is 'humanising' the other or becoming our other selves" (McLaughlin 5). This humanizing treatment involves understanding the cultural differences between the two groups. Unfortunately, this does not happen in Rita's case; she is accused of prostitution just because she accepted money from a strange man. She admits that she "was picked up by some men who gave me five dollars. An' then they arrested me" (17). She is hungry and could not find a job to sustain herself. She begs the Magistrate to let her "go home... jus' let me go home. I can't get out of jail to find the highway. or some kind of a job!" (58). She is, as if, caught inside a spider web with no way out. Considering her deplorable condition, how could she refuse the money she was offered? In addition, she is too naïve to know the real intentions of the undercover office .

Moreover, Jaimie, another Aboriginal living in the city, admits that they lose their identity and become a part of the menial working flocks. He says: "in the city they never learn my name. It was "fella," "You boy". That kind of stuff" (69). Towards the end of the play, he screams to regain his stolen identity which was lost from him in the city. He wants the Whites to help him by "“"teach[ing] me who I really am! You've taken that away! Give me back the real me so I can live like a man!" (111). His identity is his means for surviving in the cold and cruel world of the city, where he lost his dignity as an Indian. In the end, JAIME declares that he "believe[s] nobody, No priest nor government... They don't know what it's like to want an' not have. to stand in line an' nobody sees you!" (106). He is fed up with the White man's intolerance with the Natives. He ends up being carried by Rita's father as his "body is placed down on the podium, beside RITA JOE's." (125) After Rita, he is the second victim to the oppression of the Whites.

This paper hopes to trace the intercultural journey of the two Aboriginals, who represent every other youthful Aboriginal, as they aspire to achieve something in their life outside the confinement of their reserves. They see their bright future in the city. Their primary flaw is that they have a strong desire to maintain their Aboriginal identity. Wilfred Guerin et al. declare that "in many immigrant literatures, one notes the frequency of autobiographical tropes of crossing over, of being in cultural hiding, of alienation within mainstream culture, of creating new identities" (294). In the imperial settler society of the cities, the Aboriginals face constant and strong shifts in the cultural and colonial powers which marginalized them. Lawrence Grossberg, Cary Nelson, and Paula Treichler emphasize that the intellectual promise of cultural studies lies in its attempts to "cut across diverse social and political interests and address many of the struggles within the current scene" (1-3). In light of the previous quote, crossing the cultural border between the reserves and the city becomes a symbol of the Aboriginals' struggle to achieve decolonization and liberation. It is worth noting that George Ryga first called the play Twilight to a Long Long Day. When he revised the text, he renamed it The Ecstasy of Rita Joe. It is also quite interesting that the play is partly based on real-life incidents. Ryga thought about writing this play after reading an article in a newspaper. The "newspaper article was likely a feature by Vancouver Sun reporter Simma Holt, who, noting the death of a Native girl in a garbage-dump area on Cordova Street did some research and discovered about twenty such tragedies" (Hoffman, The Ecstasy 159). He memorializes the trauma of these Aboriginals in his play. The dead bodies of Rita and Jaimie act as a direct signifier that encodes their peoples' culture/s violated by the settlers' colonization. The play contains heartfelt moments of racial and cultural clashes where the Aboriginals open their hearts, to be heard and healed.

Barbara Godard believes that such postcolonial literary texts can be regarded as "a testimony to the variety and vitality, the quantity and quality of cultural productions by Native artists." These texts are important signs of the "emergence of Native culture as a forceful presence in literary institutions" (110). It is an acknowledged datum that minority writers are using literature as a means of peacefully empowering their literary stand and situating their own people within the body of the hegemonic narratives of their colonizers. Bain Attwood emphasises the significance of such literary texts by saying that "the humanity of many has been restored, the identities of minority peoples have been recognized, the inner or subjective aspects of the human past have been recuperated, and some historical losses have been repaired" (89). In general, these literary texts can help in changing the White society and its outlook towards the welfare of the Aboriginals. In his "The Indian in Contemporary North American Drama," Peter Szaffko describes George Ryga not as an author, but rather an influential "critic who has been consciously dealing with oppressed minorities in contemporary Western societies; his Indian and The Ecstasy of Rita Joe are highly symbolic works of art which place the Indian question among the most current social problems in Canada" (184). Such texts aim, in their essence, at "centering our concerns and worldviews and coming to know and understand theory and research from our own perspectives and for our own purposes" (Smith 39). This idea is very clear when the young Native girl arrives to the city with her friend Jaimie 
Paul in search of work and a better life. Jaimie begins the play in a happy atmosphere: "jubilant, his laughter blending with her laughter. At the sound of his voice, RITA JOE runs to him, to the memory of him... his mood light and childlike" (19). Unfortunately, what they ultimately find is racism, poverty, obstacles, and a world that they are not ready or fully equipped to dwell in. The plot of the play, in two acts, is very simple. Yet the playwright has exerted great efforts to depict the injustices of the White society. George Ryga, as a writer who enjoyed "episodic fragments", used flashbacks, montages, and tableaus to tell his story (Hoffman, The Ecstasy 9). The Aboriginal heroine of the play, Rita Joe, and her boyfriend leave the reserve where they have been brought up and start, in Ryga's words, "an odyssey through hell" (qtd. in Hoffman, The Ecstasy 166). After her arrival in the city, she realizes that her gender would be a problem for her, so she walks "like a stick, tryin' to keep my ass from showing because I know what they're thinkin' them bastards" (21). In vain, she tries to uncover the stereotypical image of her sexuality as a female Aboriginal.

According to Ryga, it is this idea of otherness which prevents Canadians from achieving harmony and equality. Juan Flores and George Yudice state that "the view from the border enables us to apprehend the ultimate arbitrariness of the border itself, of the forced separations and inferiorizations" (80). The paper aims to show the different attitudes of the Whites/Aboriginals regarding the crossing of Rita Joe and how people from different cultures look at each other. As Toelken puts it, "we will often see what our culture trained us to see" (17). Whoever attempts to cross this border needs to be completely assimilated into the hegemonic mainstream; otherwise the person shall be excluded and degraded. It is interesting to note that colonization forces the minorities to convince themselves to be "the marginal, the underdeveloped, the periphery, [and] the 'Other'" (Hall 396). These negative colonial feelings once forced Frantz Fanon to admit that he had to "meet the Whiteman's eyes" whenever he had to cross these lines. These crossings were like "an unfamiliar weight [that] burdened' him. At these moments, he admitted, that "I was responsible for my body, my race, for my ancestors. I discovered my blackness, my ethnic characteristics; and I was battered down by tom-toms, cannibalism, intellectual deficienc , fetishism, racial defects, slaveships" (294-5). These lines open the stinging and infectious injuries from which many Aboriginals have suffered. These very injuries condense the incidents in George Ryga's The Ecstasy of Rita Joe.

In the play, George Ryga criticizes the socio-cultural system in Canada. The play is not just a condemnation of "institutionalized racism and imposed poverty... it is also a frank statement that the situation will not change until key questions of Aboriginal sovereignty and economic redress are tackled" (Dickinson 209). The play seems to suggest many forthright questions: Can literature help in breaking the walls separating different cultures? If we assume that these barriers are made to protect the outlining identity of a group from change and evolution, does crossing require the fusion of one culture with the other? Living in the age of political tur- moil and cultural confusion, can this crossing be successful without amalgamating one's true defining identity with that of the other? Is cultural crossing measured by loss and gain? Gloria Anzaldua states that crossing means a new-born mestia, a hybrid that retains its connectedness to its roots while assuming a new cultural identity (78). It is clear that Ryga chooses an authentic and earthly character to speak about the situations these Natives are encountering daily in the cities. In his story, Rita represents the many Aboriginals who seek the illusion of freedom and a brighter future, which they believe can be found in the city. Rita Joe declares that she wants "to be free" (84), she wants to be heard (83). George Ryga wants his audience and his readers to take a stand. In the preface to the play, Ryga cites a very interesting review written by Chief Dan George of the Burrard Tribe, declaring that "the play carries a message all Canada should hear... [he] was amazed at the reaction the play received. People came to [him] to say that now, for the first time, they understood a little of what the Native Peoples have suffered and are suffering" (5). To carry forward his mission of educating his audience about the situation of the Aboriginals, George Ryga devotes his play to state the responsibility of the Westerners in perpetuating the problems of the Natives. Briefl, "we witness the narratives of a society desperately fractured by its colonial past" (Hoffman, George Ryga 11). He starts by commenting on the role of schools in making the Natives forget their own culture and leading them to assimilate into the culture of the White Anglos. The teacher explains the imperial, cultural idea of the melting pot to the young children, saying that "there's a lot [they] don't know... That kind of behavior is exhibitionism! [They] are a melting pot!... [We] put copper and tin into a melting pot and out comes bronze...It's the same with people!" (64). But at the end of the class, she gets impatient, saying that Natives "will never make bronze! Coming from nowhere and going no place! Who [is she] to change that?" (66). She could not perform her supposed role of teaching the naïve, young, Native children something useful. Instead, she hints at the stereotypical ideas about the Aboriginals being stupid and slow-witted. The play expresses the uselessness of the education offered by the White settlers to the Aboriginal Canadians. The play is neither confrontational nor submissive, but its criticism is very obvious.

In addition, it is notable that Ryga gives examples of a few different representatives of the hegemonic White authority in the city, such as the Priest, the Magistrate, and the Policeman. James Barber describes the play as "a documentary of the Indian problem ... a misunderstood people... caught up in the irreconcilable conflict that arises from imposing the urban and organized values of society on simple, rural children" (qtd. in Conolly 58). Ryga comments on the passive role of the churches in the Natives' lives when Rita narrates the story told by her uncle: "long ago the white man come with Bibles to talk to [her] people, who had the land. They talk for hundred years...then [the Natives] had all the Bibles and the white man had [their] land" (84). Ironically, her uncle narrates how the religious Westerners used their religion to steal the land from the Natives in the name of the 
Christ. When Rita asks for the PRIEST's help, he "stiffly" answers, "we will only be free if we become humble again" (84). He discourages the calls of the Aboriginals for freedom and human rights. Rita knows that the Priest cannot help her in the city. She screams at him to "go tell your God. about Rita Joe an' what [the Whites] done to her! Tell him about yourself too! That you were not good enough for me" (85). These honest screams emit a very harsh reality, contrary to the supposed holistic intentions of the Whites as the liberators of the poor and supposedly uncivilized Natives.

Ryga also questions the political legitimacy of judging the Natives just for being different. This serious accusation is quite clearly expressed in the unsympathetic attitude of the Magistrate towards the protagonist. He asks the poor, hungry, and homeless Rita if she "had [her] teeth fixed ever?" or "[her] lungs x-rayed recently?" (74). He keeps standing before this helpless, young girl with a "rambling confidence of detached authority" and tells her that the Whites "came up as a civilization", something that has been rejected by the Natives. In this, he accuses the Indians of being barbarous savages. He continues his tirade about how the Whites have built schools and they "won't attend them because they're out of the way and that little extra effort is too much for you!" The whites have provided "medical attention" to drunken Natives who would have ended up dead. He adds that the Whites have "good job, if you'd only look around a bit." He concludes by declaring that the Natives' "reliability record is ruined" (117-118). Ironically, he advices her to "fix [her] hair...perhaps even change [her] name. And try to tame that accent that sounds like [she has] a mouthful of sawdust...There is no peace in being extraordinary!" (52) i.e. being a Native. In this racist society, being different means being rejected. In conclusion, George Ryga admits that the Whites suppose that Natives are passive. They "look wise and wait forever" to get their lawful rights (90), they are "lazy, undependable" (118), and filthy (117). Rita's real crime is her inability to assimilate into the Anglo-Canadian social life. Tariq Modood believes that "racism normally makes a linkage between a difference in physical appearance and a perceived difference in group attitudes and behavior" (164). Rita could not understand this when the Magistrate tells her: "the obstacles to your life are here... in your thoughts...possibly even in your culture" (51). In saying this, he is referring to the real reason Rita is on trial - she could not forget her familial and cultural traditions. She has failed to assimilate into the Western culture. Ryga is trying to express his universal disdain and intolerance of the racial injustices faced by Natives, as represented by Rita, in the courts of law, when he writes, "She craves communion with people, with the MAGISTRATE" (24). Nobody respects her enough to listen to what she says. Even the Magistrate falls in this same category: "He does not relate to her. She is troubled" (19), because "his mind elsewhere" (25). She laments in despair, "I don't think God hears me here. Nobody hears me now" (83). Wasserman comments on the play, saying: "Rita is struggling to preserve her integrity in the face of a system socially and politically designed to frustrate her every attempt to make sense of her life" (24). This is very clear when she says that the society "got rules that was made before [she] was born ... [they] can't understand [she] was hungry when [she] stole something" (77). Ryga describes the play as "A Renaissance and a voice for social change" (qtd. in Innes 190). Indeed, Indians need some kind of help to survive in the face of their cruel society.

Ryga cleverly uses the character of Mr. Homer, the apparently sympathetic White social activist, to criticise the supposed mission of civilizing the Natives. Homer runs a Centre to help the Aboriginals in the city. Ironically, he believes that the "cure" to the Indian problems is "a bowl of stew under the belt and a good night's sleep" (52). He keeps bragging about how the Centre helps the Aboriginal women whose husbands leave them to become "drunken Indians" (36). It is quite clear that he knows nothing of their problems and worries to speak about them. His mind and heart are so loaded with the stereotypical images of the Aboriginals that he fails to see the humanistic side of their dilemma. He resents the drunkenness of their men without bothering to ask why they tend to drink. In many cases, they tend to do so in order to escape their present, because they could not handle the harsh reality of being subjugated and controlled in their own land. Apparently, Homer's character represents the church's and/or the government's infantilization of the Aboriginals. Ryga is referring to the Indian Act of 1876 which resulted in marginalizing the Aboriginals, "making them a special class of persons, legal dependents on the crown and children in the eyes of the law" (Harring 263). Jaimie "points after MR. HOMER" and says, "he's got no kids... Guys like that get mean when they got no kids... We're his kids an 'he means to keep it that way!" However, Jaimie now realizes that this situation should change, "Well, I'm a big boy now!" (97). As an Aboriginal, Jaimie recognises that Homer "is the worst kind" among the colonizers. Towards the end of the play, Homer reveals his actual, vicious character when he starts to call Rita and Jaimie as "sonofabitch", "slut... breed whore" (109). He admits that the Society for Aid "wanted Indian to show up at their annual dinner. No speeches or fancy stuff. just be there" (94), revealing that all those charity endeavours are only for the fame and propaganda. Jaimie summarizes the need of the Whites for Indians - "that stay proud even when they hurt... just so long's they don't ask for their rights!" (113). Ironically, one cannot stay proud without claiming one's rights as a free human.

The play is full of social, political, and cultural problems discussed from a rather humanitarian viewpoint. In the "Introduction" of the play, Peter Hay postulates that the "play did not focus on any particular issue so much as on the whole problem - white man's denial of the Indian humanity" (9). To achieve the aims of its author, the play is loaded with "the frequent use of verbal irony and word play", in a way that "the ex-centric, be they Canadians, women, or both, can subvert the authority of [the English] language and its final meaning" (Gallant 65). Ironically enough, in a scene where Jaimie is very hungry, he notices that "Kids feed popcorn to seagulls... an' I think to myself... Boy! Pigeons eat pretty good here!" (20). On the other hand, George Ryga employs a very powerful element of irony, which is clear even in the 
names of the characters as Rita Joe, and Mr. Homer, the prejudiced White social activist who considers himself to be the great saver of the Natives. Even the title of the play is ironic. After seeing the humiliation and the suffering Rita has faced, we can rightfully say that she would find her ecstasy only in being a martyr, doomed because of her cultural identity. It is very interesting to realise the "sharp distinction between the remembered happiness of childhood in the country and the harsh realities of adult life in the city." (Carson 39). It is not a coincidence that we never see her laughing joyfully, except in her dreams.

A very vital theatrical aspect of the play, that adds to its importance, is the Brechtian use of songs and music to comment on the dilemma of the Aboriginals. Robert Leach believes that "song is a self-contained process which makes its own concrete contribution, functioning as an informer, a nark. This is only successful, however, when the music is given its own space" (128). At the beginning of the play, Ryga specifies that the singer is "turned away from the focus of the play. Her songs and accompaniment appear almost accidental. She has all the reactions of a white liberal folklorist with a limited concern and understanding of an ethnic dilemma which she touches in the course of her research and work in compiling and writing folk songs. "According to these details, the singer definitely represents the Western audience in their indifference to the Aboriginals' dilemma. Ryga adds that the singer "serves too as an alter ego to RITA $J O E$ " (15). In addition, she is the chorus of the play. In a very unique way, the songs comment on the incidents and the characters of the play. Three times in the play, the singer sings:

Sleepless hours, heavy nights,

Dream your dreams so pretty.

God was gonna have a laugh

An' gave me a job in the city! (87, 92 \& 111).

The singer paradoxically recalls the Natives' dreams of living a decent life and having a secure job in the city. She ends the play lamenting the deaths of Rita and Jaimie and describing them as birds who have finally found their freedom

Oh, the singing bird

Has found its wings

And it's soaring!

My God, what a sight!

On the cold fresh wind of morning!... (125)

The singer emphasises that in this world, these Aboriginals will not get their freedom, except as helpless victims of the Western colonial system.

The whole play seems to take place in one day. George Ryga has managed to portray Rita's sufferings by presenting her own memories and fascinations. During the play, the past of the young girl gets mixed along with her present. Rita keeps waking "from her dream, cold, shaking, desperate" (80). Her life is changed forever, her dreams are shattered over the harsh reality she is experiencing in the city. Jaimie sorrowfully expresses the dreams of all young Aboriginals when they arrive to the cities. He thinks "we're gonna work an' live like people. not be afraid all the time" (69). George Ryga dramatically uses the character of Rita's Father to act as a symbol of the Natives' wisdom. He seeks to preserve their identity as well as their lands in face of the Whites' hegemonic colonization. He knows that many young Natives die in the city. The Natives could not believe the stories he tells about the horrible consequences of crossing the lines between the reserves and the city (103). He could not think of a way to warn his daughter, Rita, "of the animals there... who sleep with sore stomachs because they eat too much?" while the Natives are starving (104). Near the end of the play, he "pauses for a long moment to embrace and forgive [Rita] everything" and exits without looking back (115). His departure may indicate his death or his desperation for a social change. The play ends with a ritualistic Indian scene around the bodies of the two martyrs: Rita and Jaimie -

All the Indians, young and old, kneel around the two bodies. The FATHER continues his death chant. The PRIEST enters from the wings of stage right reciting a prayer. The TEACHER, SINGER, POLICEMAN and MURDERERS come with him forming the outside perimeter around the Indian funeral. (125)

The two have lost their lives as a result of chasing a fantasy that did not exist. But does the play threaten all Aboriginals of the same consequences on leaving their reserves and warn them against crossing over? What is the answer offered by the play to the dreams of the Aboriginals? Are the messages of the play directed towards the Aboriginals or to the Whites?

The problem with Rita is that she has crossed the border while being emotionally attached to her Aboriginal culture and her personal outlook. She did not try to embrace the other, nor they her. For any cultural crossing to be successful, it has to include an intellectual dialogue between the different parties involved in this crossing. This dialogue should indicate that both participants have equal social and political powers, to learn about not only each other but also about each other's cultural identities. The play shows that unequipped crossing can be fatal. It is very important to have both the worldviews respected and valued for both their differences and their similarities. The play is a literal representation of the Aboriginals' views, attitudes, and pains as they cross over to the other side. The harsh reality portrayed in the story is that these Aboriginals are moving inside the realm of their own country, in which they have lived for thousands of years before the arrival of the White usurpers. The play is a picture of the similarities and differences within the same society, and a testimony that delivers an important call to maintain integrity within the Canadian society. Moreover, it is very important to acknowledge the complicated status of the Native communities and the agony of their histories. This can be considered as the wakeup call for the White Canadians as well as the Aboriginals. George Ryga is calling for intercultural competence of the Aboriginals and empathy for their behaviour and their ways of thinking.

\section{REFERENCES}

Anzaldua, Gloria. Border Lands La Frontera: The New Metiza. Aunt Lute Books, 1987.

Attwood, Bain. "In the Age of Testimony: The Stolen Generations Narrative, Distance and Public History." Public Culture, vol. 20, no.1, 2008, pp. 75-95. 
Benson, Robert. Children of the Dragonfly: Native American Voices on Child Custody and Education. Arizona UP, 2001.

Carson, Neil. "George Ryga and the Lost Country." Canadian Literature, no. 45, 1970, pp. 33-40. Accessed 2 Mar. 2017.

Conolly, Leonard. Canadian Drama and the Critic. Talonbooks, 1987.

Dickinson, Peter. "Murdered and Missing Women: Performing Indigenous Cultural Memory in British Columbia and Beyond." Theatre Survey, vol. 55, no. 2, May 2014, pp. 202-232. Accessed 5 Mar 2107.

Douglas, Vasiliki. Introduction to Aboriginal Health and Health Care in Canada: Bridging Health and Healing. Springer, 2013.

Flores, Juan, and George Yudice. "Living Borders/Buscando America: Languages of Latino Self-Formation." Social Text, no. 24, 1990, pp. 57-84. Accessed 17. Apr. 2017.

Frantz, Fanon. Black Skin White Mask. Translated by Charles Markmann. Grove Press, 1967.

Gallant, Mavis. Home Truths: Selected Canadian Stories. Macmillan, 1981.

Godard, Barbara. Canadian Literature at the Crossroads of Language and Culture. Newest Press, 2008.

Grekul, Lisa. Leaving Shadows: Literature in English by Canada's Ukrainians. Alberta UP, 2005.

Grossberg, Lawrence, Cary Nelson, and Paula Treichler, editors. Cultural Studies. Routledge, 1992.

Guerin, Wilfred, et al. A Handbook of Critical Approaches to Literature. Oxford UP, 2005.

Hall, Stuart. "Cultural Identity and Diaspora." Identity: Community, Culture, Difference, edited by Jonathan Rutherford, Lawrence, 1992, pp. 392-405.

Harring, Sidney. White Man's Law: Native People in Nineteenth-Century Canadian Jurisprudence. University of Toronto Press, 1998.

Hoffman, James. George Ryga: The Other Plays. Taloon Books, 2004.

---, ed. The Ecstasy of Resistance: a Biography of George Ryga. ECW Press, 1995.
Innes, Christopher. "The Psychology of Politics: George Ryga's Captives of the Faceless Drummer." Theatre Research in Canada, vol. 6, no.1, Spring 1985): n. pag. Accessed1 Mar 2017.

Kearney, Michael. Changing Fields of Anthropology: From Local to Global. Bowman and Littlefield, 2004

Kirkness, Verna, and Sheena Bowman. First Nations and Schools: Triumphs and Struggles. Canadian Education Association, 1992.

Leach, Robert. Makers of Modern Theatre. Routledge, 2004.

McLaughlin, Marianne. Crossing Cultural Borders: A Journey towards Understanding and Celebration in Aboriginal Australian and Non-Aboriginal Australian Contexts. Dissertation, Curtin University, 2012.

Modood, Tariq. "Difference: cultural racism and anti-racism." Debating Cultural Hybridity: Multi-cultural Identities and the Politics of Anti-racism, edited by Pnina Werbner and Tariq Modood, Zed Books, 1997, pp.155-172.

Peters, Evelyn. "Aboriginal Public Policy in Urban Areas: an Introduction." Urban Aboriginal Policy Making in Canadian Municipalities, edited by Evelyn Peters, McGill-Queen's UP, 2011, pp. 1-32.

Ryga, George. The Ecstasy of Rita Joe. Talonbooks, 2004.

---. Summerland/George Ryga. Edited by Ann Kujundzic. Talonbooks, 1992.

Smith, Linda. Decolonizing Methodologies: Research and Indigenous Peoples. Otago UP, 1999.

Szaffko, Peter. "The Indian in Contemporary North American Drama." Canadian Drama, vol.13, no. 2, 1987, pp. 182-186.

Toelken, Barre. "Seeing With the Native Eye: How Many Sheep Will it Hold?" Seeing With the Native Eye: Essays on Native American.

Religion, edited by.

Walter Capps, Harper and Row, 1976, pp. 9-24.

Wasserman, Jerry. Modern Canadian Plays. Talonbooks, 1986. 